\author{
Krzysztof Parzych ${ }^{1}$ \\ Institute of Socio-Economical Geography and Tourism \\ Pomeranian University in Słupsk, Poland
}

\title{
Technical background to the conference tourism in polish accommodation objects
}

\begin{abstract}
An analysis of the technical facilities of conference tourism in accommodation facilities adapted for the organization of conference meetings in Poland and individual voivodships indicates significant spatial differences and a strong concentration of the potential of the technical facilities of conference tourism.

The largest number of accommodation facilities equipped with conference rooms, the largest number of conference rooms and the number of places in conference rooms are characterized by the most urbanized voivodships (Masovian/mazowieckie), Lesser Poland/małopolskie, Lower Silesian/dolnoślaskie, Greater Poland/wielkopolskie, Silesian/ślaskie, West Pomeranian/ zachodniopomorskie and Pomeranian), whose main administrative centers are the largest urban agglomerations in Poland. This confirms the general trends of the location of conference tourism and its connections with large urban agglomerations. In addition, hotel facilities adapted to perform the conference function in these voivodships have the best technical facilities for organizing conference meetings.

The weakest conference facilities, the smallest number of facilities, rooms, beds and facilities with appropriate technical facilities are characterized by peripheral and poorly urbanized voivodships (Opole Voivodeship, Świętokrzyskie, Podlaskie). The high dynamics of the development of conference tourism in Poland is characteristic, which is confirmed by the clear increase in the number of facilities adapted to perform the function of conference tourism reception, the number of rooms and conference rooms as well as the high dynamics of increase in the technical elements of accommodation facilities adapted to perform the function of the conference. This phenomenon is observable in the country as a whole and in all individual provinces.
\end{abstract}

Outline of content: This study analyzes the technical facilities of conference tourism of Poland's accommodation facilities in the administrative system of provinces. The problem analysis was made for all voivodships in Poland based on the data of the Central Data Bank of the Statistics Poland. In addition, an analysis of the spatial distribution of technical elements of accommodation facilities for the needs of

\footnotetext{
${ }^{1}$ Krzysztof Parzych, e-mail: krzysztof-parzych@wp.pl, ORCID: 0000-0002-1784-4539
} 
conference tourism was carried out. The analysis of the problem was made in relation to data from 2009 and 2017.

Keywords: conference tourism, technical facilities, Poland

\section{Introduction}

The political transformation in Poland in the 1990s and subsequent years and the related changes in the free market economy had a significant impact on the functioning of the tourism market. The tourist traffic and tourist development of Poland was previously associated primarily with social tourism, organized by large workplaces concentrated in the largest agglomerations and urban-industrial centers of Poland. In addition, an important role in the organization of tourism was played by the Workers' Holiday Fund, whose role was to finance the participation of professionally active people in tourism. Individually organized tourism played a much smaller role. The material base of tourism has been dominated for many years by seasonal accommodation facilities concentrated primarily in coastal, mountainous and lakeside resorts associated with large industrial plants. They were mostly facilities with a fairly low standard of equipment, aimed at mass service of tourists coming to rest in the summer holiday months. Socio-economic changes in the early 1990s caused quantitative and structural changes in the development and tourism of Poland. A significant proportion of accommodation facilities, so far, seasonal, have been closed down. In their place new facilities began to appear, with a much higher standard of equipment, comprehensively adapted to the reception of other leisure facilities. Along with the growing number of tourist facilities, the number of tourists, new facilities equipped for the reception of modern forms of tourism began to appear more and more often, min. wellness, spa, and the growing socio-economic importance of Poland in the international arena were accompanied by an increase in the number of foreign tourists.

Economic changes were also associated with an increase in business travel, both domestic and foreign. These factors have created the need to adapt the existing accommodation base and construction of new facilities for the needs of business tourism, including conference tourism. In Poland, this segment of tourism is just developing. However, due to the generally high dynamics of the development of conference tourism in the world, especially in Europe (almost $60 \%$ of all arrivals within the framework of conference tourism is directed to European countries) one can expect a growing role of Poland in the reception of international conference tourism. Conference tourism in the structure of other forms of tourism is often included in the group of broadly defined business tourism. On the other hand, however, the dynamics of its development and the growing rank among other "business" trips mean that it is distinguished as a separate type of tourism, including participation in training conferences, congresses or symposia. Davidson (2011) in its classification of conference and congress meetings distinguishes company meetings, i.e. group meetings of employees of a given company, association meetings, i.e. group 
meetings of members of a given industry organization, other meetings, which include visits by government bodies, non-governmental structures and religious and trade unions.

Conference tourism is characterized by lower price sensitivity in comparison with other forms of tourism, very high profitability, the highest standard of the material base and services rendered, low seasonality related to the much more evenly distributed use of the material base throughout the year, with a decrease in the holiday and vacation period, which is due to the fact that the majority of conference travel is business travel. The issue of conference tourism is also an increasingly popular topic in scientific research. Some studies on conference tourism capture it in the broader context of business tourism (Bartosiewicz et al. 2005, Borodako 2013, Davidson et al. 2003, Iwan 2011, Iwan 2012a, Sala 2008, Siemiński 2009, Świątecki 2005). The topic of conference tourism is increasingly being addressed directly. The studies are carried out at various spatial scales, both national and regional (Celuch 2008, Celuch et al. 2011, Iwan 2012). In addition to strictly scientific studies, CSO or industry institutions' reports on conference tourism (MPI Future Watch, 2011, Measuring the Economic Importance of the Meetings Industry Developing a Tourism Satellite Account Extension, 2006, Meetings industry in Warsaw. Report 2012, Report from hotel market in Poland, 2010, Tourism Development Directions until 2015, 2008. Report Meeting industry in Warsaw 2010, providing rich source material for other scientific and research studies. In research issues related to the development of conference tourism there are also works close to the undertaken in developing the problem, technical background of conference tourism (Jagusiewicz 2010).

\section{Purpose of the study}

The purpose of this study was to analyze the technical equipment of Poland's accommodation facilities for the needs of the functioning and development of conference tourism. The study was based on statistical data of the Central Statistical Office of the Central Statistical Office in relation to data from 2017 and selected issues of 2009. The problem is presented in the system of data on individual provinces. In his analysis, the following were taken into account: the number of facilities adapted for the organization of conferences, the total number of conference rooms, the number of seats in conference rooms and data on the technical equipment of conference rooms: i.e. the number of rooms with sound system, with a wireless microphone, with a multimedia projector, with a set enabling implementation of videoconferences, with professional staff service, with a screen, with a flipchart, with a desktop computer or notebook, and with the availability of wifi in the facilities. 


\section{Analysis of results}

In total, in 2017 in Poland 3680 accommodation facilities, adapted to the organization of conferences and other meetings of the nature of conference tourism. Their spatial distribution indicates strong spatial concentration (fig.1)

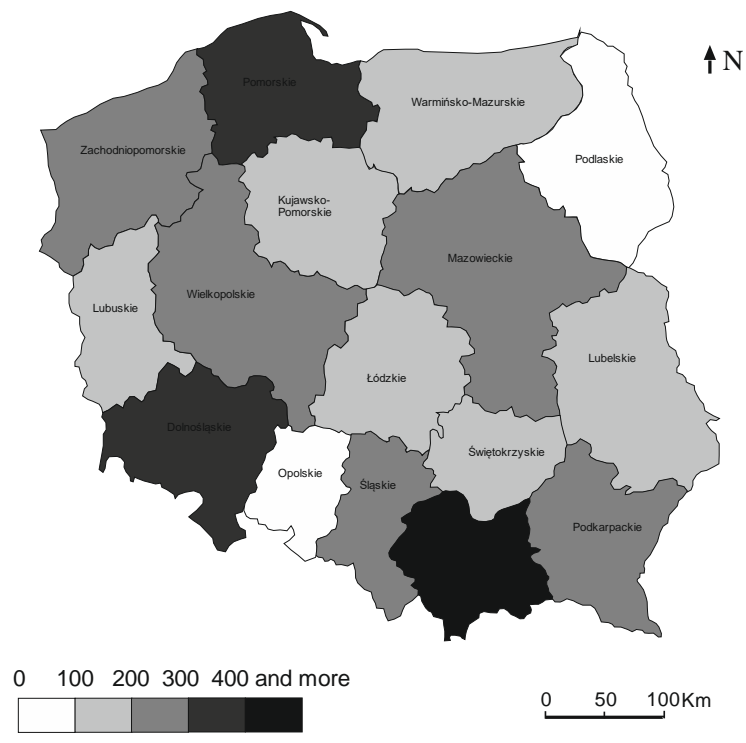

Fig 1. Spatial arrangement of hotel facilities equipped with conference rooms Source: own study based on the data of the CSO Local Data Bank.

Most of these accommodation facilities equipped with conference rooms were in the following provinces: Lesser Poland-509, Lower Silesian-334 and Pomeranian-327. The fewest accommodation facilities equipped with conference rooms were in the following voivodships: Opole Voivodeship-80, Podlaskie-99 and Świętokrzyskie-111 and Lubusz/lubuskie-125 (Fig. 1). In total, in Poland's accommodation facilities in 2017, there were 8,193 conference rooms according to the Statistics Poland data. An analysis of their distribution of accommodation facilities in individual provinces indicates similarly large spatial disparities (Fig. 2). The largest number of conference rooms were located in the accommodation base of the following voivodships: Masovian-1173, Lesser Poland-1081, Lower Silesia-720 and Greater Poland-674 and Silesian-657. The fewest conference rooms were in the accommodation base of Opole-151, Podlaskie-191 and Lubusz- 206. 


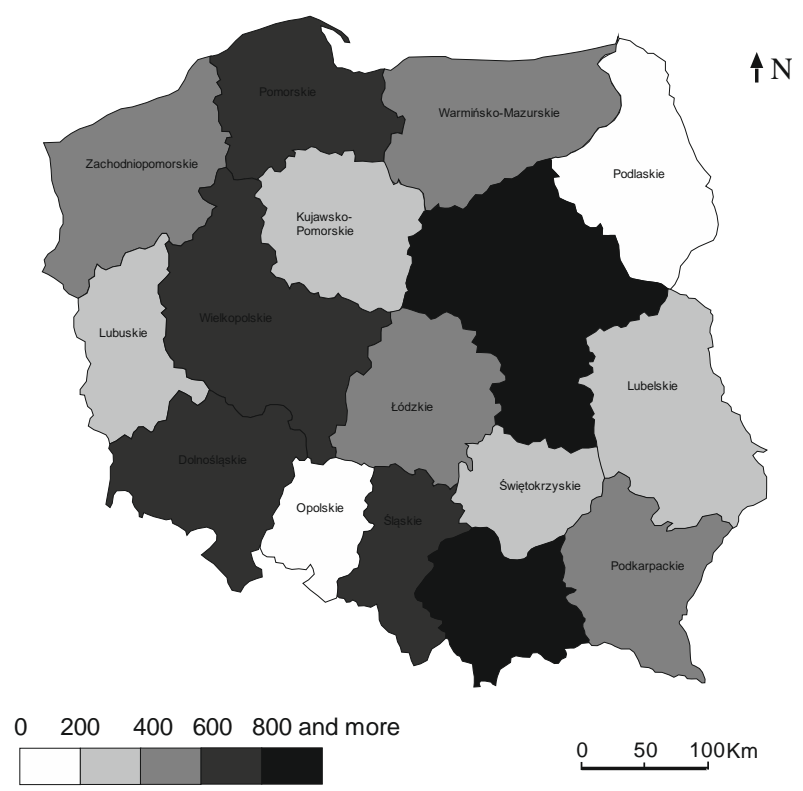

Fig. 2 Number of conference rooms in accommodation facilities of individual voivodships

Source: own study based on the data of the CSO Local Data Bank.

It is worth noting the systematic increase in the number of accommodation facilities equipped with conference rooms as well as the number of conference rooms in Poland in total and in individual voivodships in the years 2009-2017. In 2009, the number of accommodation facilities equipped with conference rooms was -2851 , in 2013-3467, in 2017-3680. In 2009, there were 6014 conference rooms in the facilities of the Polish accommodation base, in 2013-7651, and in 2017-8193. The highest increase in facilities equipped with conference rooms were recorded in the following voivodeships: Lublin/lubelskie, from 110 in 2009 to 193 in 2017, Masovian, from 214 to 296, Warmian-Masurian/warmińsko-mazurskie from 127 to 181 . The highest increase in the number of conference rooms was recorded in the following voivodeships: Lublin, from 200 in 2009 to 353 in 2017, Opole, from 93 to 151, Kuyavian-Pomeranian, from 240 to 378 and Masovian, from 773 to 1172. 


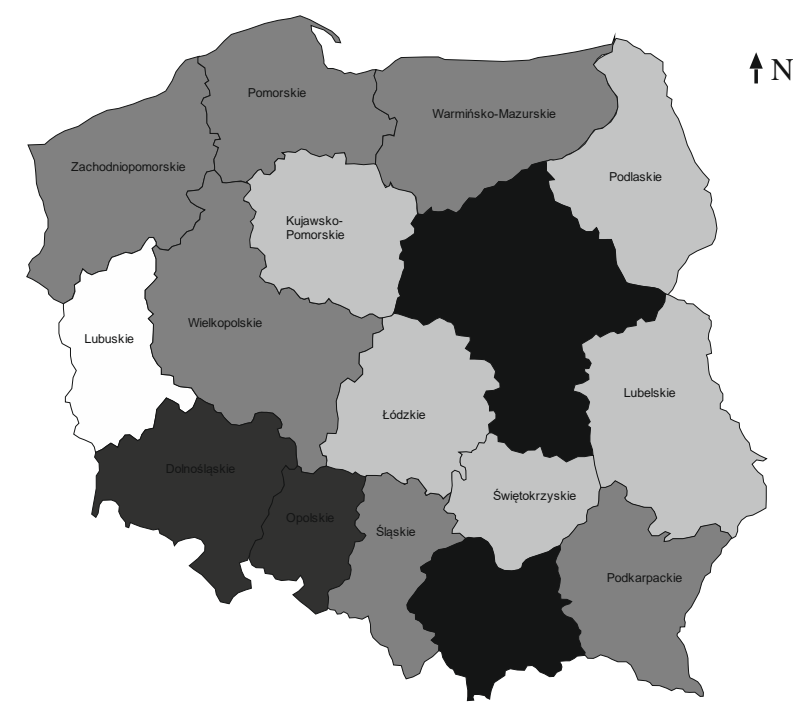

015000300004500060000 and more

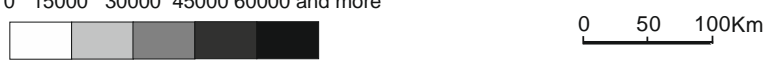

Fig. 3 Number of places in the conference rooms of accommodation facilities in following voivodships

Source: own study based on the data of the CSO Local Data Bank.

The analysis of the arrangement of places in the conference rooms of the accommodation facilities of individual voivodships confirms previous trends (Fig. 3) In total, in 2017 in the conference rooms in Poland there were 55,594 beds. The largest number of seats in the conference rooms were available in the following voivodships: Masovian - 71 388, Lesser Poland - 70 053, Lower Silesian - 46735 and Silesian - 45081. The smallest places in conference rooms were in the following voivodships: Opole Voivodeship-8 552, Lubusz-11 208 and Podlaskie - 15651 places. Compared to 2009 (376,941 seats), there was a $32.1 \%$ increase in the number of beds in conference rooms in 2017. The highest dynamics of the increase in the number of seats in conference rooms was recorded in Lublin (56.5\%), Podkarpackie (52.3\%) and Kuyavian-Pomeranian $(49.0 \%)$ voivodships. In other voivodships, the number of places increased by over $20.0 \%$.

A strong spatial concentration of the number of facilities equipped with conference rooms, the number of conference rooms and places in conference rooms in the most urbanized voivodships: Masovian, Lesser Poland, and Lower Silesian is noticeable. At the same time, they are voivodships with the largest concentration of year-round accommodation base and voivodships in which the largest urban agglomerations in Poland are located. This confirms the strong connection between the material base of conference tourism and the conference services market with large urban and industrial agglomerations. 


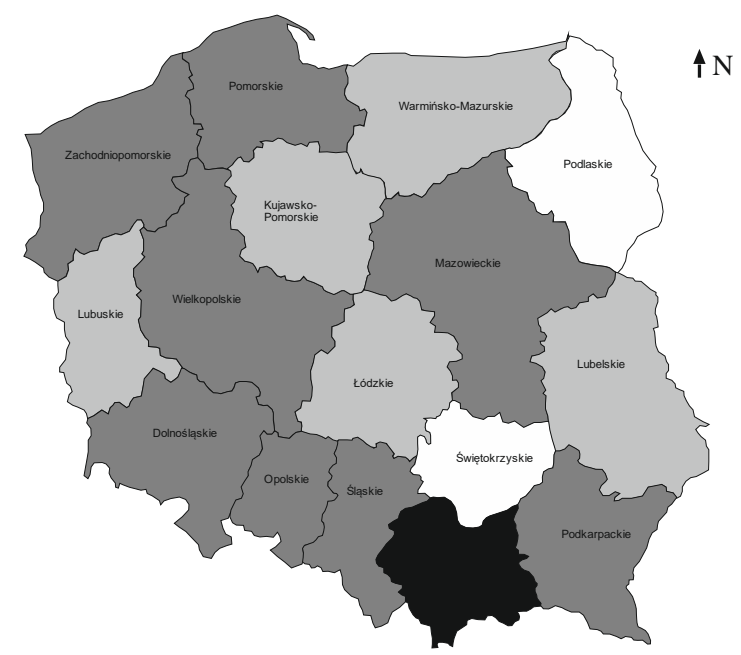

$0 \quad 100200300$ and more

$\underline{0 \quad 50 \quad 100 \mathrm{Km}}$

Fig. 4 Number of conference rooms with sound system in accommodation facilities of following voivodships

Source: own study based on the data of the CSO Local Data Bank.

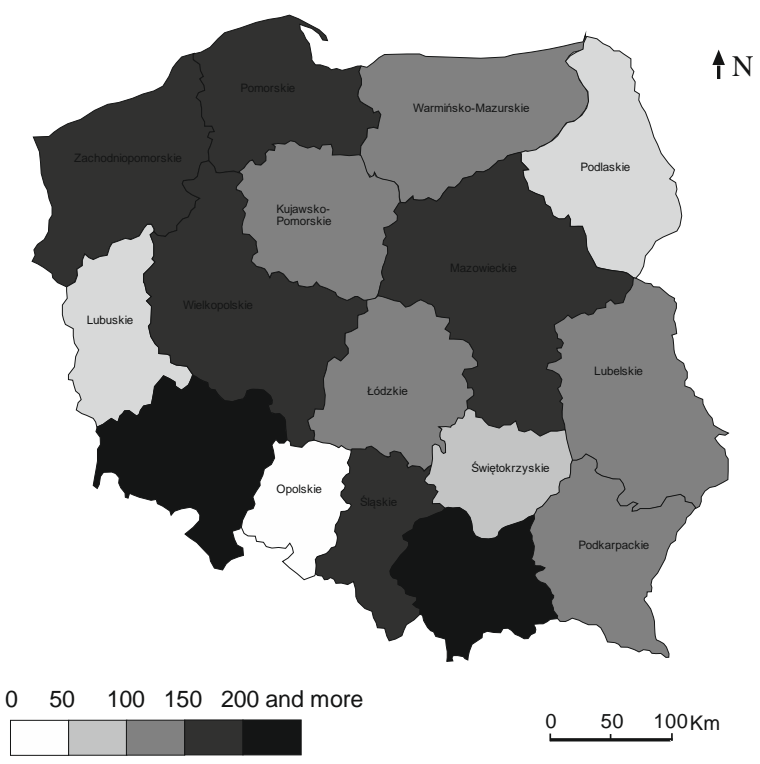

Fig. 5 Number of conference rooms with technical support at accommodation facilities of individual provinces

Source: own study based on the data of the CSO Local Data Bank. 
An important element characterizing the technical infrastructure serving the needs of the functioning and development of conference tourism is the technical equipment of the facilities. In addition to location, it plays a major role in making location decisions regarding conferences, congresses, seminars and other scientific and business meetings. Appropriate sound system, high-class computer equipment, wifi connections, equipping conference rooms with video equipment, projectors, screens, slide projectors, audio video sets and other devices enabling implementation as well as an appropriate image and sound standard for video conferences (sets) plays an important role here. for video conferences, internet connections).

The human factor is also important here, i.e. the preparation of staff responsible for efficient technical service of conference meetings. In 2017, there were a total of 3,159 conference facilities in Poland with a sound system enabling the implementation of the conference (Fig. 4).

Table 1. Elements of equipment for conference rooms of accommodation facilities of follow voivodships

\begin{tabular}{|c|c|c|c|c|c|c|c|c|c|}
\hline Voivodships & $\begin{array}{l}\text { With the sound } \\
\text { system }\end{array}$ & $\begin{array}{l}\text { With the } \\
\text { projector }\end{array}$ & $\begin{array}{l}\text { With the } \\
\text { Videoconference } \\
\text { kid }\end{array}$ & $\begin{array}{l}\text { With slide } \\
\text { projector }\end{array}$ & $\begin{array}{l}\text { With video } \\
\text { system }\end{array}$ & $\begin{array}{l}\text { With } \\
\text { screen }\end{array}$ & $\begin{array}{l}\text { With } \\
\text { flipchart }\end{array}$ & $\begin{array}{l}\text { With the } \\
\text { computer }\end{array}$ & $\begin{array}{l}\text { With Wi- } \\
\text { Fi access }\end{array}$ \\
\hline Lower Silesian & 275 & 304 & 92 & 263 & 231 & 349 & 312 & 252 & 619 \\
\hline Kuyavian-Pomeranian & 136 & 162 & 54 & 112 & 92 & 155 & 141 & 105 & 265 \\
\hline Lublin & 155 & 170 & 45 & 105 & 79 & 173 & 165 & 129 & 304 \\
\hline Lubusz & 92 & 103 & 31 & 94 & 57 & 116 & 91 & 74 & 184 \\
\hline Łódź & 126 & 139 & 34 & 156 & 114 & 163 & 150 & 98 & 250 \\
\hline Lesser Poland & 380 & 467 & 151 & 385 & 334 & 492 & 470 & 407 & 1128 \\
\hline Masovian & 236 & 256 & 87 & 213 & 156 & 276 & 272 & 198 & 425 \\
\hline Opole & 59 & 72 & 16 & 39 & 39 & 75 & 66 & 56 & 122 \\
\hline Subkarpatian & 188 & 204 & 51 & 151 & 129 & 229 & 191 & 191 & 444 \\
\hline Podlaskie & 81 & 92 & 32 & 61 & 49 & 89 & 87 & 70 & 190 \\
\hline Pomeranian & 255 & 269 & 73 & 248 & 215 & 313 & 280 & 214 & 994 \\
\hline Silesian & 230 & 255 & 77 & 226 & 182 & 287 & 251 & 207 & 461 \\
\hline Świętokrzyskie & 97 & 96 & 33 & 88 & 64 & 102 & 89 & 80 & 185 \\
\hline Warmian-Masurian & 147 & 159 & 44 & 137 & 107 & 173 & 167 & 140 & 316 \\
\hline Greater Poland & 221 & 263 & 74 & 252 & 199 & 282 & 263 & 186 & 454 \\
\hline West Pomeranian & 240 & 261 & 79 & 201 & 197 & 273 & 235 & 216 & 948 \\
\hline Total & 2918 & 3272 & 973 & 2731 & 2244 & 3547 & 3230 & 2623 & 7289 \\
\hline
\end{tabular}

Most of this type of facilities were in the following provinces: Lesser Poland-418, Pomeranian-287, Lower Silesian-284 and West Pomeranian-261, the least in voivodships: Opole-64, Podlaskie-85 and Świętokrzyskie-99. Compared to 2009, there was an almost $32.0 \%$ increase in this type of facilities, of which the most in Lublin (53.2\%) and Opole Voivodeship (45.2\%). In 2017, there were 2918 conference rooms in Poland equipped with a microphone. Compared to 2009, there was a $44.9 \%$ increase in this type of facilities. The largest number of conference rooms equipped with a microphone in 2017 was in the following provinces: Lesser Poland380, Lower Silesian-275, Pomeranian-255, West Pomeranian-240, the least in voivodships: Opole Voivodeship-59, Podlaskie-81, Lubusz-92 and Świętokrzyskie97. An important factor conditioning the appropriate level of conference meetings is qualified technical staff trained in the operation of equipment enabling the 
organization of conference meetings. In 2017, there were 2132 conference facilities in Poland with staff to provide conference services. Most of this type of facilities were in the following provinces: Lesser Poland-287, Lower Silesian-224, Masovian-192, Pomeranian-178 and West Pomeranian-170, the smallest in the voivodships: Opole Voivodeship-35, Lubusz-57, Świętokrzyskie-58 and in Podlaskie-60 (Figure 5). In relation to 2009 , there is a $28.7 \%$ increase in the number of such facilities. In addition, in 2017, 3272 facilities adapted for the organization of conference meetings were equipped with projectors, most of which in the following provinces: Lesser Poland467, Lower Silesian-304, Pomeranian-269, the least in voivodships: Opole Voivodeship-72, Podlaskie 92, Świętokrzyskie-96. 973 facilities were equipped with sets for organizing video conferences, of which the largest number of such facilities was located in the following provinces: Lesser Poland-151, Lower Silesian-9, Masovian-87, West Pomeranian-79, least in voivodships: Opole Voivodeship-16, L ubuskie-31, Świętokrzyskie -33, Łódź-34. The slide projectors according to the data of the CSO Local Data Bank in 2017 were equipped in Poland - 2731 objects, of which the most in the following voivodeship: Lesser Poland-385, Lower Silesian-263, Greater Poland-242, Pomeranian-248, the least in voivodships: Opole Voivodeship39, Podlaskie-61, Świętokrzyskie-88, Lubusz-94. A total of 2,244 conference facilities were equipped with video sets. Most of this type of facilities were in the following provinces: Lesser Poland-334, Lower Silesian-231, Pomeranian-215, Greater Poland-199 and in West Pomeranian-197, the least in voivodships: Opole Voivodeship-39, Podlaskie-49, Lubusz-57 and Świętokrzyskie-64. Conference facilities equipped with a screen were in total in 2017 - 3547, of which the most in the following provinces: Lesser Poland - 492, Lower Silesian - 349, Pomeranian - 313, Greater Poland - 282, Masovian- 276, the least in voivodships: Opole Voivodeship 75, Podlaskie - 89 and in Świętokrzyskie - 102. There were 3230 facilities equipped with dry-wipe boards (flipcharts) in Poland in 2017 adapted to organizing conference meetings, most of them in the following voivodships: Lesser Poland- 470, Lower Silesian- 313, Pomeranian- 280, Masovian- 272, least in the voivodships: Opole Voivodeship-66, Podlaskie-87, Lubusz-91. In addition, in 2012623 conference facilities in Poland had computer sets for organizing conference meetings, of which the most in the following provinces: Lesser Poland-407, Lower Silesian-252, West Pomeranian-216 and Pomeranian-214, the least in the following voivodships: Podlaskie - 70, Lubusz - 74 and Świętokrzyskie - 80. In 2017, there were 7,289 facilities adapted for organization of conference meetings in Poland, of which the most were in the following provinces: Lesser Poland - 1128, Pomeranian - 994, West Pomeranian - 948, Lower Silesian - 619, the least in voivodships: Opole Voivodeship - 122 , Lubusz-184, Świętokrzyskie-185. 


\section{References:}

Bartoszewicz W., Borne-Januła H., Skalska T. (2005), Turystyka biznesowa w Polsce, Instytut Turystyki, Warszawa.

Borodako K. (2013), Turystyka biznesowa w Krakowie na tle innych miast Polski, Prace Geograficzne, v. 134, p. 69-81.

Celuch K. (2008), Definicje i interpretacje pojęć [in:] Turystyka biznesowa. Produkt i promocja, Stowarzyszenie Konferencje i Kongresy w Polsce, Warszawa.

Celuch K. (2012), Przemyst spotkań $i$ wydarzeń w Polsce - Poland Meetings and Events Industry. Raport, Wyd. Polskiej Organizacji Turystycznej, Warszawa.

Celuch K., Dziedzic E. (2010), Raport. Przemyst spotkań $i$ wydarzeń w Polsce, Convention Burea of Poland, Warszawa.

Celuch K., Dziedzic E. (2011), Przemyst spotkań $i$ wydarzeń w Polsce - Poland Meetings and Events Industry. Raport, Publ. House Polska Organizacja Turystyczna, Warszawa.

Davidson R. (2011), EIBTM Trends Industry Report, Reed Travel Exhibition, Barcelona.

Davidson R., Cope B. (2003), Business Travel: Conferences, Incentive Travel, Exhibitions, Corporate Hospitality and Corporate Travel, Pearson Education, Harlow.

Eurosystem (2010), Raport. Przemyst spotkań w Warszawie 2010, Warszawa.

Hotelarz (2010), Raport z rynku hotelarskiego w Polsce.

Iwan B. (2011), Rodzaje i zakres turystyki biznesowej, „Zeszyty Naukowe WSTIJO”, v. $8(2)$.

Iwan B. (2012a), Czynniki rozwoju turystyki biznesowej w Polsce, [in:] Turystyka biznesowa. Determinanty rozwoju, B. Iwan, M. Kacprzak (eds.), Warszawa.

Iwan B. (2012b), Rozwój turystyki targowo-wystawienniczej w wybranych miastach Polski, „Zeszyty Naukowe WSTIJO”, v. 10 (2).

Jagusiewicz A. (2010), Zaplecze konferencyjne $w$ turystycznych obiektach noclegowych $w$ Polsce, Instytut Turystyki, Warszawa.

Meeting Professionals International (2011), MPI Future Watch, Dallas.

Ministerstwo Sportu i Turystyki, Kierunki Rozwoju Turystyki do 2015 roku 2008, Warszawa.

Przemysł spotkań w Warszawie (2012), Raport 2012, Warszawa.

Sala J. (2008), Turystyka biznesowa a rozwój hotelarstwa w Polsce, Zeszyty Naukowe Uniwersytetu Ekonomicznego w Krakowie, 788, p. 5-21.

Sidorkiewicz M. (2011), Turystyka biznesowa, Warszawa.

Siemiński J. (2009), Kształcenie następnego pokolenia profesjonalistów $w$ branży turystyki biznesowej: problemy i rozwiazania, Warszawa.

Świątecki A., (2005), Nowy Incentive w Polsce, Warszawa.

UNWTO (2006), Measuring the Economic Importance of the Meetings Industry Developing a Tourism Satellite Account Extension, Madrid. 